\title{
Wenzel Matiaske*
}

\section{Pourquoi pas? Rational Choice as a Basic Theory of HRM ${ }^{* *}$}

A broad spectrum of theories from different disciplines is portrayed in contemporary HRM (as a discipline of business administration). Theories from psychology, sociology and economics correspond to the variety of problems addressed in HRM which are again situated at different levels of analysis, namely on the individual, group and organizational level. A narrow focus solely on economic approaches, as sometimes suggested in personnel economics, is therefore not sufficient.

Instead, the contemporary "rational choice" approach may serve as a "new" basis for the discipline. The approach stems from economics and sociology and, as an offspring of these, combines elements of action and structure in its basic explanatory models. Also it is able to explain effects that emerge on the system or macro level. Indepth explanations allow model building at different levels of analysis, namely on an environmental, organizational and individual level, which can be seen as a major prerequisite of explanations in HRM. In addition "rational choice" is conscious of the ignorance of its underlying action theory and this exposes it to the body of physiological and psychological knowledge. Anomalies of classic economic theory can therefore be restricted, for instance by using the method of decreasing abstraction. The method of decreasing abstraction serves as a basic principle or heuristic device for model building, in order to separate "rational choice" from traditional anti-reductionism.

This article introduces basic elements of the modern "rational choice" approach: the macro-micro-macro model of explanation, homo socio-oeconomicus as a model of man and exchange theory as a baseline model of aggregation. A final summary discusses research questions and applications of "rational choice" in HRM.

\section{Key words: Rational Choice, Economic Sociology, Micro-macro-link, Homo Socio-oeconomicus}

* Prof. Dr. Wenzel Matiaske, University of Flensburg, Institutes of International Management and Sociology, Munketoft 3b, D - 24937 Flensburg, Germany, Phone: ++49 461805 2546. E-Mail: matiaske@uni-flensburg.de.

** "Pourquoi pas" or "Why not" is the title of a French movie released in 1977 and directed by Coline Serreau. It describes a relationship of three people. Such a "ménage à trois" stands up for discussion in this article as well, even though it evolves between disciplines. As in real life, one of the actors is paid more attention than the other.

Article received: February 25, 2004

Revised version accepted after double blind review: April 18, 2004. 


\section{Approach}

Ever since Pareto's (1935) distinction, it has generally been agreed, that the field of economics should concentrate on rational action; other areas of social science, i.e. sociology should concentrate on irrational behavior. However, economics is a broad field. Therefore it is hardly surprising that economists who are confronted with irrational human behavior or deviations from the perfect model of purposeful and rational behavior wrangle with Pareto and, in particular, with his line of distinction. Critical calls were confronted with only modest appreciation, if they were heard at all, when they suggested that unrealistic assumptions about behavior were required in order to deliver economic or normatively speaking "good" explanations (Friedman 1953). Academics in Business Administration, dealing with innovation, marketing, organization or human resources and phenomena like decision behavior, informal organizations or HRM abandoned the economic paradigm and searched for more feasible theories in other disciplines.

The historical development of HRM is not the topic of this article. However, we need to stress that we are talking about a process of convergence towards neighboring disciplines, notably (social) psychology and (organizational and industrial) sociology, which represent a "long wave" of historical ideas: Simon's (1955) revolutionary work "A behavioral model of rational choice" was published half a century ago. Since then, considerable progress has been made in both theory and empirical knowledge. And this holds true for all levels of HRM research - for the individual, group and organizational level. Worth mentioning amongst others are motivation, learning and stress theories, theories about group dynamics, power and management as well as theories about organizations and their environments. Furthermore, it is worth emphasizing tendencies towards empirical social research which evolved at the same time as behavioral science.

Economic theory was "exported" once again into HRM with the rediscovery of institutions in economic research and the development of appropriate models, such as property rights, transaction costs and information asymmetry, which all facilitated the explanation of the failure of the free market model of traditional economics (Coase 1960, Alchian/Allen 1972). Criticism from business administration that human resources academics lacked economic background and that the adaptation of theories from other disciplines caused little more than interdisciplinary dilettantism only increased the influence of economics. ${ }^{1}$ Personnel economics (Lazear 1996; Sadowski 2002) may be called the rearguard of this new "economic imperialism."

1 For the German discussion see Ordelheide et al. (1990). In the German case, one needs to consider that business administration is not organized within business schools but is studied within a department. The subject of business administration is not multidisciplinary and aligned around the subject matter of the firm as it applies to the study of public administration in Germany and in an anglo-american Business School, but German business administration departments raise the claim of unity in the understanding of the discipline. This type of organization undoubtedly has some advantages. However, the coherence gained can cause difficulties, if for example academics in HR have to deal with lets say formal models of HR planning and anomalies in group decision processes simultaneously. 
Conquerers are usually confronted with resistance. While representatives of New Institutional Economics tried to keep in touch with HRM, above all via the psychology of individual decision behavior and economic sociology (Kabst 2004), most personnel economists remained ignorant to the theoretical and empirical fund of knowledge of their own discipline. Whether this is - in the long-run - a successful strategy to attain hegemony in the field of ideas will be left up to scientific historians. However, in my modest view success is much more likely if one bases his arguments in an agreable way without always expecting agreement. As there were and still are good reasons why some disciplines of business administration, and especially such ones like HRM, are no longer willing to rely on economics unconditionally, it may be a reasonable proposal to underpin HRM with a theoretical basis which takes into account the fragmentation of the discipline and the individual results of each fragment. What we are talking about, finally, is nothing less than the "unity of social science."

Such a proposal is up for discussion in this article. The contemporary version of "rational choice" in sociology once again aims at merging together knowledge of different social sciences following the tradition of Max Weber's "understanding sociology". 2 The initiators of the program can be found in scientific theory (Popper 1994; Albert 2003), economics (Akerlof 1984; Becker 1976), sociology (Boudon 1981; Coleman 1984) and organizational theory (March/Simon 1993; Olson 1965). The main representatives of the approach are Esser (1999), Kirchgässner (1991), Lindenberg (1985) and Swedberg (2003) (amongst others). This may suffice to locate the program, as we are not discussing positions of individual authors in this article but the overall framework of the program. This framework can be summarized by three main points because codification is well advanced: The standard model of explanation also called the macro-micro-macro model (chapter 2), the model of man in "rational choice" (chapter 3) and exchange theory as the most popular model of "aggregation" (chapter 4) are discussed in the following chapters. The article concludes with reflections on possible HR-applications of the framework (chapter 5).

\section{The "Macro-Micro-Macro" Model}

The following thoughts might be trivial from an economist's view. As far as economics is concerned it has never aimed at the explanation of individual behavior but at collective or social results of individual decisions. Price theory can be considered a standard economic example. Price is determined by the interaction of demand, i.e. a buyer with preferences and a defined budget, and supply, i.e. goods with certain costs of production and distribution. From a psychologist's view the concentration on the micro-macro transition may be incomprehensible. From his view collective effects of individual behavior are taken for granted but his prime interest is in individual outcomes in response to certain, even collective stimuli. As a result, it is hardly surprising

2 Different labels can be used to describe the program. Labels like "new micro-sociology", "new micro-economics" or "economic sociology" can apply. The author tends to prefer the name "socio-economics" which describes the theory more accurately as being on a borderline between economics and sociology. Due to didactical demarcation, we keep the label originating from action theory. 
that it was left to sociology to explain macro-micro transitions more precisely (Alexander et al. 1987).

"Rational choice" in this interpretation can be seen as an elaboration of different lines of what has been called "methodological individualism": Explanations aim at collective results of individual behavior, not at individual behavior itself. This is nothing new for the field of HRM. A typical example is the explanation of how motivated individual behavior can be transformed into collective performance which again serves the aims of the organization.

Figure 1: The macro-micro-macro model

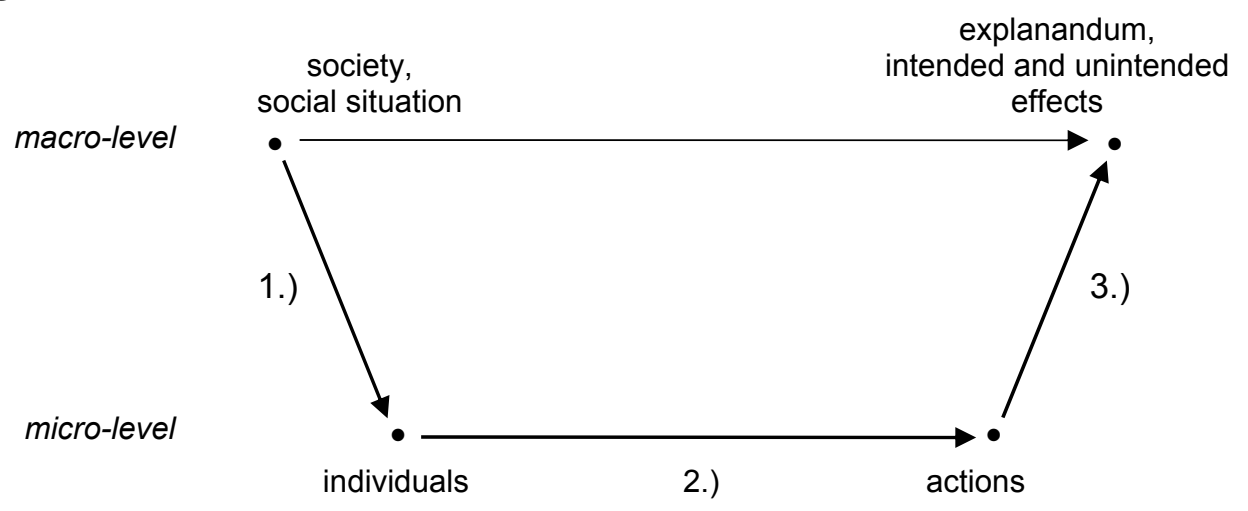

The macro-micro-macro model (figure 1, Boudon 1981; Coleman 1990) represents the common glue of explanations proposed within the theoretical framework of ,rational choice"; it serves as the core element of the theory. Structural variables describe the social situations of actors and represent the starting point of explanation. Individual behavior is then explained in respect to the circumstances it is situated in. Again, this requires an individual action theory. According to Lewin's (1951) programmatic formula which defines behavior as a function of situation and person, this can be characterized as the social-psychological part of the model. However, the explanation of individual behavior is not an end to itself. Individual behavior serves as a basis for the explanation of intentional and/or unintentional collective and/or emerging effects. This part of the model corresponds to the example of economic price theory. Therefore the theory does not choose the direct path between social situations and collective results which is usually preferred by macro theories of sociology and economics; instead, it follows the rules of methodological individualism and disaggregates the task into three relatively autonomous steps: the logic of the situation, the logic of selection and the logic of aggregation.

1) The logic of the situation - a concept which can be traced back to Poppers' (1994) thoughts on social theory - combines the macro level of the action system with the micro level of actors. To this purpose so-called bridge assumptions must be stated, i.e. more or less abstract and typical assumptions which characterize the social situation from an actors' points of view. In the most simple case of completely informed actors, one can assume that the actors know their objective behavioral options. The bridge assumptions can then be refined step by step in order to depict subjective compo- 
nents of the observed situation. For example, concepts of socialization and learning theories can be included in order to model positional and dispositional effects on behalf of the actors under study. It will often be impossible to adequately refine the bridge assumptions because of "missing data" or "missing information" on individual views of the logic of the situation. However, as we are not talking about individuals and their idiosyncratic characters but about collective explanations, for "economic" reasons knowledge about typical views and typical actors is regarded as sufficient for model building.

2) The logic of selection depicts the nomological core of the model. From a methodological point of view this step implies the choice of an action theory which connects actors and actions on the micro level of explanation. Typically, "rational choice"theory draws on different versions of valence-expectancy theory ${ }^{3}$ which is well known and acknowledged in economics as well as in psychology and sociology. The choice of SEU-theory (Subjectively-Expected-Utility) is frequently appropriate but not compelling. Above all, the "rational choice" approach formulates a number of criteria the chosen action theory should comply to (Wippler/Lindenberg 1987):

- According to its nomological status the action theory should possess a high degree of generalization and contain little information about the individual.

- It must be able to consider structural conditions of actions, i.e. it must allow the formulation of bridge assumptions in the modelling of the logic of the situation; it should also enable the modelling of collective results of actions.

- Assumptions should not be axiomatically fixed by premises such as complete information; it should always be possible to integrate or to model assumptions derived from physiological and psychological theories. Furthermore, the amount of "ignorance" of the action theory should be made explicit, so that more complex assumptions can enter the model, e.g. using the method of decreasing abstraction (Lindenberg 1992).

- Finally, action theory should consider the underlying model of man, namely homo socio-oeconomicus. It must take into account the free will of individuals and that individuals are resourceful (see chapter 3).

These rules can be interpreted as methodological guidelines for the construction of explanations or models. They help to balance out the conflicting goals between the explanation of individual actions and the logic of aggregation (in principle, the former implies the explanation of every individual action, while the latter can only consider typical actions). Thus, the rules require that shortcomings of the action theory are made explicit so that it can be refined if necessary.

3 An axiomatic version of subjectively-expected-utility theory (SEU-theory), an expression which is often used synonymously for valence-expectancy theory, can be traced back to von Neumann/Morgenstern (1972). Schoemaker (1982) gives an overview of the various versions of the theory. Heckhausen (1989) summarizes findings from motivation theory in this regard. It is worth mentioning that the so-called VIE-theory by Vroom (1964), which is widely accepted and used in behavioral HRM and Organizational Science, is likewise only a special variation of SEU- or valence-expectancy theory. 
3) The most decisive step is the logic of aggregation. So-called transformation rules are needed, so that individual interaction processes can be modeled. Depending on the system under study formal aggregation models such as election rules may be appropiate. In many practical cases in HRM simple additive models are sufficient, for example in the case of collective phenomena such as turnover, absenteeism or participation in training courses which can be modeled by simple rates or quota. In many cases, the logic of aggregation will have to take into account combinations or the conjunction of individual actions. In these cases, assumptions must be made on how individual actions influence each other in the process of aggregation. Diffusion, game or exchange theories may be helpful in this regard. One very popular model is exchange theory (see part 4). However, exchange theory is only one aggregation model which is frequently used due to its manifold applicability. Further standard models of aggregation include resources allocation models (Coleman 1975, Vanberg 1982) which explain why individuals join up to form associations or organizations. Another example is made up by "threshold models" (Granovetter 1978) which come into use when collective panics, revolts or also fashions are to be modeled.

By now it should have become clear that the "rational choice" approach in HRM focusses on collective phenomena of organized actions. Thus, in this respect it is close to personnel economics. However, "rational choice" approach is aware of the ignorance of its underlying action theory and is therefore open to integrate findings from social-psychological theories. In more detail, this means that the ignorance of the action theory in use is made explicit and methodological rules, like the method decreasing abstraction, can be used to avoid the introduction of (psychological) ad hoc assumptions - which are common in standard economic research. The method of decreasing abstraction protects the core of the argumentation, namely the action theory in use, and first of all recommends improvements in the logic of aggregation and the logic of the situation. But, in order to eliminate major anomalies of explanation it opens the nomological core to physiological and/or psychological findings. For this purpose, it is necessary and indeed possible to extend the macro-micro-macro model of explanation by a further (in-depth) level of analysis. Thus, "rational choice" is separated from antireductionism - which has a long history in social science from Durkheim (1982) to Popper (1969) - without giving up the independence of social explanations.

Such in-depth explanations, which - as proposed by Coleman (1990) - further differentiate the self in an object self and an acting self, will apply, in my view, only to few applications in standard HRM. As HRM considers organizations and the markets and environment the organizations operate in, it will be more important to use indepth explanations to bridge the gap between environment, organizations and individuals and to develop unifying models of explanation. How do organizations (meso level) act in respect to globalization processes (macro level) and which options are chosen by its members (micro level) which, in turn, effect the strategy of the organization (meso level) and the process of globalization (macro level)? These are relevant questions HRM is confronted with. The example proves that it is possible to integrate environment, organizations and individuals in explanations within a "rational choice" framework. Generic or dynamic explanations, which are scarce in today's HRM, are possible if several macro-micro-macro explanations are connected in series. 


\section{Homo Socio-oeconomicus}

In particular researchers from behavioral sciences loathe a solely rational model of man. Even reformist movements in the line of the so-called new economic institutionalism could not change this attitude. While the "traditional" homo oeconomicus of the standard micro-economic literature was depicted as a "heartless calculating machine", the "new" and strictly opportunistic homo oeconomicus in institutional economics is pictured as a bunch of no-gooders, which spoils the next generations of academics and business men (Pfeffer 1994).

So let's recapitulate: It was less a problem with the "old" homo oeconomicus, whose only joy in life was money, that he would have sold his mother-in-law at the next best opportunity - and therefore no rationally thinking economist would have wanted such a chap as a son-in-law, as Boulding (1969) once remarked. The "old" and under-socialized homo oeconomicus would not have come into the awkward situation of selling his mother-in-law as he was a devout single. The problem of economics with its pupil was that he could only survive within the perfect markets of neo-classical standard theory. Social autism of homo oeconomicus clearly marked the boundaries of economic thought. This became clear with reflections on market failures, e.g. in the context of environmental pollution. The awareness of market failures directed the attention of (welfare) economics not only to the overlooked marginal conditions necessary for perfect markets to function - property rights, lacking transaction costs and perfect information (Coase 1960) - but blessed traditional homo oeconomicus with a few new abilities as well. In imperfect markets it is no longer sufficient to be able to calculate and maximize but also to negotiate and to undergo tactics. Opportunism (Williamson 1985) - which incorporates calculation as well as cunning - does not make the chap any kinder but keeps him functioning in imperfect markets. In addition, economists like Arrow (1963), Downs (1957) or Becker (1976) used their theoretical repertoire to analyze non-economic institutions like politics, education or even families. The extension was only enabled because homo oeconomicus besides money got used to the maximization votes, investments in education and finally in social approval as well. New micro-economics thus once again discovered characteristics which classical institutionalists like Smith (1911), Veblen (1924) or Schumpeter (1942) had already known. The way from the maximization of profits to the maximization of utility and the so-called assumption of "alchianesque" utilities (Alchian/Allen 1972) have definitely been further prerequisites of the new institutionalism in micro-economics.

There was a parallel discussion in sociology about the model of classical structural functionalism, homo sociologicus. He was used to dealing with expectations as he met social norms and institutions and he appreciated societal values which guided his behavior in the form of deeply internalized standards (Parsons 1962; Kluckhohn 1962; Dahrendorf 1977). Unfortunately, homo sociologicus as a member of the upper middle class (Mills 1959) did not get in contact with constraints and calculation seemed disrespectful to him. This made it even more difficult for theorists to analyse daviating behavior. Homo sociologicus does not break rules: he does not buy more than he can 
pay for, does not embezzle money and does not rob banks (Diamond 1971). ${ }^{4}$ Thus, this over-socialized representative (Wrong 1961) of the weird and spooky men in the social sciences accentuated the limitations of sociological action theory in a prominent way. Critics such as Homans (1964) pleaded for a reorientation of action theory almost half a century ago. Homans connected the recollection of rational action in sociological theory to an address for the extension of the utility concept. Homans argued for a revival of a homo calculus who besides material values appreciated social values as well. Thus, he thought of a theoretical man whose behavioral spectrum ranged from altruism to hedonism, and who in respect of the economic principle did not waste his scarce resources.

Figure 2: The characteristics of homo socio-oeconomicus and his relatives

\begin{tabular}{lccc}
\hline & homo oeconomicus & homo sociologicus & $\begin{array}{c}\text { homo socio- } \\
\text { oeconomicus }\end{array}$ \\
\hline Resourceful & $\bullet$ & $\bullet$ \\
Restricted & $\bullet$ & $\bullet$ \\
Evaluating & & $\bullet$ & $\bullet$ \\
Expecting & $\bullet$ & & $\bullet$ \\
Maximizing & & $\bullet$ & $\bullet$ \\
\hline
\end{tabular}

The models of man in the tradition of these thoughts have been codified in different ways. Meckling (1976) as an economist suggested REMM as an orientation for new micro-economics. The Resourceful, Evaluating and Maximizing Man combines characteristics of homo oeconomicus and homo sociologicus. Lindenberg (1985, 1990), a sociologist, adds two further assumptions: restrictions, which may be trivial to economists and which of course do not only mean material but also social restrictions, and expectations, which specify the calculating characteristic more precisely (see figure 2). This new man of the social sciences, who is known as RREEMM in accordance with his characteristics, or homo socio-oeconomicus (Weise 1989), has already established himself in the middle of economics and sociology. Within "rational choice" RREEMM purely serves to exemplify methodological rules, namely the method of decreasing abstraction, and the assumptions of the underlying action theory.

The utility concept must be explicated with homo socio-oeconomicus as a model of man. This is of great importance, as economists, usually confronted with market exchange, tend to keep the utility concept unspecified and instead to draw back on money as a transaction medium (implicitly assuming that somehow "everything" can be exchanged for money). Sociologists on the other side must fill the utility concept. Various suggestions have been made to bring theory into the construction of so-called bridge assumptions (Kelle/Lüdemann 1995). Lindenberg (1996) for example draws on the classical Scottish moral philosophers and suggests two major goals - physical wellbeing and social approval. Matiaske (1999) argues for situational explanations of utility

This applies as well, if for different reasons, to the traditional homo oeconomicus, to which Diamond refers here. See the discussion in Williamson (1985), from where the reference to Diamond was taken. 
and refers to content theories of motivation. Regardless of the suggestion one chooses: It is important to replace the "empty" utility concept by empirically testable hypotheses. However, preferences should be held constant in both versions (March/Simon 1993), even if one does not have to assume that preferences change just as slowly as the Rocky Mountains (Stigler/Becker 1977).

The resistance RREEMM is confronted with while he is trying to merge some common aspects of economics and sociology is hardly understandable. Resistance arises especially with the assumption of "resourcefulness" which is sometimes intrepreted rather one-sided and biased as within new institutional economics for example. The transaction cost approach as well as information economics interpret resourcefulness as a kind of economics of "lying and deceiving". Especially the transaction cost approach as proposed by Williamson (1985) encouraged such an intrepretation by defining opportunism as intentional actions like misleading, distorting, hiding, blurring or concealing. The often strongly biased assumptions on the resourcefulness of homo-socio-oeconomicus may help explain the vehement reactions against it.

From a theoretical point of view the biased interpretation of "resourcefulness" cannot be justified. Homo socio-oeconomicus does not only use his "new" autonomy for dirty tricks; he also lures and attracts and he knows that friendliness and trust may be better means to an end than unfriendliness and mistrust. One could summarize these types of behavior - which are quite the opposite of the standard interpretation of opportunism - as self-motivated altruism because they are enacted in favor of somebody else in order to achieve one's own goals. Even "true" altrusim or on the other side of the behavioral spectrum sadism are possible behavioral alternatives. In these extreme versions of resourcefulness ego knows the utility function of alter and incorporates it into his own one, thereby increasing or reducing the utility of alter without respect of his own costs. But above all such a model demands a large amount of information about the actors which is inconsistent with the methodological rule that the action theory should be restricted on only few assumptions about actors. One will frequently operate with a simple version of an egoistic but neither jealous nor caring actor (Matiaske 1999).

It is important to note that in particular Williamson (1985) - who may be characterized as the main proponent of the opportunism assumption and who has been strongly critized for it - justifies the assumption implicitly with the commitment or liability of the economist towards the economic subjects. Because opportunism potentially can occur actors are usually well advised with the rule of the transaction approach to inform themselves ex ante and to safeguard themselves ex post. The line of argumentation is the same as the advice that a mother gives her son about not to get involved with girls, well knowing that one of the girls could be the most wonderful daughter-in-law in the world. After the wedding the same mother should tell off her son if he does not undertake a marital agreement but follows the romantic ideal about loyalty and devotion. One central problem of the biased interpretation becomes obvious if one imagines that fathers advise their daughters the same thing. But it is neither the right time to speak of young and rebellious attitudes towards over-caring parents in regard of the reproduction of society nor do we have the time to discuss the utility 
that business people could achieve if they ignored the advice of economists. It should be documented however, that transactions always affect at least two actors.

This is exactly the problem with the usual assumption about opportunism. It is not only the perception of human behavior that is severely biased. Much more biased is the use of this assumption in many studies of contemporary personnel economics. Literature is crowded with blue and white collar workers who do not work for the good of the business (at least not only) but solely pursue their own interests and tend to shirk. Managers on the other hand, who build up their careers on the backs of their employees, HRM departments, who exploit staff due to advantages in legal knowledge, or principals, who force agents to make morally questionable decisions, are no typical subjects of research. This ignorance towards phenomena of a misuse of power is however, not an inherent problem of rational action theory in general. The contemporary "rational choice" theory follows the maxim of relational analysis and considers power phenomena systematically in models of macro-micro-macro transition.

\section{4. (Social) Exchange as a Standard Model of "Micro-Macro Transition"}

The economic argumentation is based on exchange: Economics operate with the model of market exchange which is bound to certain and highly sophisticated social and societal prerequisites. As we know nowadays, thanks to new institutional economics, the functioning of the market exchange model implies a functioning legal system, a perfect system of informational and logistic infrastructure as well as market participants who stick to the codex of honorable business men. But trade was already carried out long before international trade agreements, container shipments and the internalization of universal social standards were established. And after all, wholly noneconomical interactions - for example the exchange of messages, recognition or gifts - can also be interpreted as exchange actions. And corresponding exchange theories can be found in disciplines such as social anthropology, social psychology or sociology as well. Therefore, exchange can be called the basic paradigm of the social sciences (Matiaske 2003).

Non-economic exchange theories are built on different theoretical grounds. For example, they are dependent on normative rules of honor (Mauss 1989), structural conditions of relationship (Levi-Strauss 1971) or learning theories (Homans 1974). Modern sociological versions of exchange theory - Emerson (1962), Blau (1964) and Coleman $(1972,1990)$ in particular - are routed somewhat deeper in economics. Contemporary versions of sociological exchange theory share the basis of methodological individualism and the rationality assumption with economics and the more general "rational choice" approach. Because these models, and this can only be outlined here, can be applied to various forms of social interactions, exchange theories are often used in the modeling of micro-macro transitions.

As the discussion about the (at first different) underlying models of man converges in economics and sociology, the debate on the (initially common) exchange theory seems to head in different directions. Economic debates increasingly focus on the forgotten parameters of the market place and thus piece by piece create a more realistic market model; the sociological discussion on the other side comes close to an ideal 
market place. The mathematical model in Coleman`s version of social exchange can be interpreted as the sociological reinvention of the Walrasian market model. And also the emerging effects of power are treated very differently. While prices and values are core issues discussed in economics, sociological exchange theories emphasize power and inequalities of power and thus social influence. Another difference lies in the assumption of a general transaction medium.

While economics tacitly relies on money and more and more explicates the marginal parameters of the market, as, for example the legal system, contemporary sociological exchange theory concentrates on the lack of a universal transaction medium like money within social exchange relationships. Because money is not required in social relationships and a safeguarding legal framework is lacking, structural equivalents must be invented to ensure and to enable exchange. Sociological exchange theory, in the tradition of classical thoughts on means of social interaction (Parsons 1977), refers to trust and social relationships in the form of social capital, which replace money as the universal medium of exchange (Matiaske 1999). These informal types of media in social exchange equal the formal media money and legal system in economic market exchange. However, the basis of the action theory is the same in economic and social exchange models.

Therefore sociological exchange theory systematically integrates the category of social capital (Bourdieu 1979, Putnam 2000). On the one hand, social capital is considered in models of social exchange via individual (trustworthy) relationships which an actor is provided with (Marsden 1983, Yamaguchi 1996). On the other hand, the collective interpretation of social capital is integrated in general agreements on norms (Colemann 1988), especially the universal norm of reciprocity (Gouldner 1960). In respect of the research methods used contemporary sociological exchange theories integrate concepts of social network analysis (Wasserman/Faust 1997). In a theoretical sense they reflect exchange relationships as socially embedded relationships (Granovetter 1985).

Thus, the circle is complete, as new institutional economics reflects on the social embeddedness of economic exchange relationships due to notoriously incomplete contracts on the one hand side and limits of the classical paradigm of goods-money exchange in the building of long-term and trustful relationships on the other hand side (Furubotn/Richter 1997). It is to be hoped that the parallel discussions in different disciplines contribute to the breaking down of interdisciplinary hurdles. Or in a slightly different way: It is to be desired, that the gains achieved by an interdisciplinary program may exceed the distinction based gains from isolated disciplines, which are solely built on rents from disciplinary barriers.

\section{Summary}

HRM can probably gain more than other disciplines of business administration - such as decision theory, marketing or organization theory - by turning to the contemporary "rational choice" approach. Considering the splintered array of multiple disciplinary approaches in HRM the discipline has always been struggling for recognition as a discipline in itself. At present there is a strong movement towards a rather narrowly interpreted basic economic paradigm, which at the same time means giving up the relationships built up to the neighboring disciplines of psychology and sociology. Howe- 
ver, there have been "good reasons" for turning the back on economics as a basic discipline and these reasons cannot be neglected because of a simple call for disciplinary solidarity; just as well there have been "good reasons" for HRM to remain a part of the field of business administration. Turning to the "rational choice" approach would relax this tension at a somewhat higher level of abstraction. The "rational choice" approach as a framework or guideline for research in the social sciences is able to integrate the central problems of HRM - man and organization - on the explicit basis of an action theory thereby focussing on aggregated effects of individual actions.

The macro-micro-macro model of explanation of "rational choice" considers the most typical problem of HRM, namely the aggregation of individual actions within and related to organizations. In this, the theory treats all "actors" the same without regard of the levels or stages they are acting on, which does not just mean progress in a theoretical but also in a normative sense. The approach does not reduce men in organizations to economic or psychological (calculating or stimulus-reflex)machines but considers men as endowed with will, creativity and resourcefulness. Apart from this, contemporary action theory allows for the adaptation of psychological findings via multi-layered in-depth explanations without giving up the autonomy of social phenomena. To be succinct, the "rational choice" approach opens opportunities for new insights into old problems and for the exploration of new ones thereby integrating the current theoretical and empirical knowledge of the HRM discipline. The following concluding examples may help to clarify this hypothesis:

- The closely related fields of work motivation and performance incentives schemes are usually examined from different disciplinary angles within HRM. Researchers from the behavioral sciences focus on (intrinsic and extrinsic) motivation, economists investigate the effects of (material) incentives. But topics closely related like, for example, organizational commitment are neglected from both sides, left up to specialists or transferred to other disciplines. The "rational choice" approach proves itself capable to systematically analyze the social embeddedness of work relationships on the basis of an explicated action theory and thus to provide a new (or first?) solution to the mystery Barnard (1938) left to HRM and organizational researchers. To interpret work relationships as kinds of gift exchange (Akerlof 1982) with regard to a model of man who strives for physical well-being as well as for social approval, is not only metaphorically but also systematically possible.

- Ever since Lewin's (Lewin et al. 1939) revolutionary studies, research on leadership has been influenced by his point of view that research on leader traits and leadership styles, with regard to changing environments, would deliver insights into management activities and thus leadership success. But one-sided research on the influence taking of leaders on their staff neglects that leaders may be led by their subordinates as well and that there are certain leadership structures among subordinates, too. A reformulation of the research problem in terms of exchange theory (first versions were submitted by Hollander 1958, Graen 1969, Zalesny and Graen 1995, or Matiaske 1995), considers the complex structure of relationships between all actors involved. This point of view brings new life to the con- 
cept of co-operative leadership because co-operation is no longer treated as a personal trait leadership style, but as an emergent and measurable result of a network structure on the macro level.

- Finally, on an organizational level questions arise about the diffusion of HR practices and politics within the context of globalization. Also on the level of the organization and close to knowledge sociology the "rational choice" approach renders explanations which might be helpful in the explanation of adaptation processes concerning US-American HR practices and politics in "old" Europe (Gooderham 1999).

The examples may clarify the potential of the "rational choice" approach. There is no doubt, that it will be no easy task to apply or realize the outlined program. However, this paper is not meant to be a simple recommendation of a "ménage à trois" of sociology, economics and psychology for HRM research. The "rational choice" approach does not only lure and entice but it is also a big challenge. In sociology, the approach has already passed the borders of economic sociology and is now striving to conquer "soft" fields such as cultural sociology - so let's see what happens to HRM.

\section{References}

Akerlof, G. A. (1982): Labor contracts as partial gift exchange. In: Quarterly Journal of Economics, 97, 543-569.

Akerlof, G. A. (1984): An Economic Theorist's Book of Tales. Cambridge: Cambridge University Press.

Albert, H. (2003): Erkenntnislehre und Sozialwissenschaft: Karl Poppers Beitrag zur Analyse sozialer Zusammenhänge. Wien: Picus Verlag.

Alchian, A. A./Allen, W. R. (1972): University Economics. Elements of Inquiry. 3rd edition, Belmont/CA: Wadsworth.

Alexander, J. C./Giesen, B./Münch, R./Smelser, N. J. (eds.) (1987): The Micro-Macro Link, Berkeley/Los Angeles/London: University of California Press.

Arrow, K. J. (1963): Social Choice and Individual Values. 2nd edition, New York: Wiley.

Barnard, C. I. (1938): The Functions of the Executive. Cambridge/MA: Harvard University Press.

Becker, G. S. (1976): The Economic Approach to Human Behavior. Chicago/London: University of Chicago Press.

Blau, P. M. (1964): Exchange and Power in Social Life. New York: John Wiley.

Boudon. R. (1981): The Logic of Social Action. London: Routledge \& Kegan Paul.

Boulding, K. E. (1969): Economics as a moral science. In: American Economic Review, 59, 1-12.

Bourdieu, P. (1979): Outline of a Theory of Practice. Cambridge: Cambridge University Press.

Coase, R. H. (1960): The problem of social costs. In: Journal of Law and Economics, 3, 1-44.

Coleman, J. S. (1972): Systems of social exchange. In: Journal of Mathematical Sociology, 2, 145-163.

Coleman, J. S. (1975): Social structure and the theory of action. In: Blau, P. M. (ed.): Approaches to the Study of Social Structure, 76-93, New York: Free Press.

Coleman, J. S. (1984): Introducing social structure into economic analysis. In: American Economic Review, 74 (2), 84-88.

Coleman, J. S. (1988): Social capital in the creation of human capital. In: American Journal of Sociology, 94 (Suppl.), 95-120.

Coleman, J. S. (1990): Foundations of Social Theory. Cambridge/MA: Havard University Press.

Dahrendorf, R. (1977): Homo Sociologicus. 15. Aufl., Opladen: Westdeutscher Verlag.

Diamond, P. (1971): Political and economic evaluation of social effects and externalities: Comment. In: Intrilligator, M. (ed.), Frontiers of Quantitative Economics, 30-32. Amsterdam: North-Holland.

Downs, A. (1957): An Economic Theory of Democracy. New York: Harper.

Durkheim, E. (1982): The Rules of Sociological Method. New York: Free Press.

Emerson, R. M. (1962): Power dependence relations. In: American Sociological Review, 27, 31-40. 
Esser, H. (1999): Soziologie: Spezielle Grundlagen. Bd. 1: Situationslogik und Handeln. Frankfurt am Main/New York: Campus.

Friedman, M. (1953): The methodology of positive economics. In: Essays in Positive Economics, 3-43. Chicago: University of Chicago Press.

Furubotn, E. G./Richter, R. (1997): Institutions and Economic Theory. Ann Arbor: Universtity of Michigan Press.

Gooderham, P. N./Nordhaug, O./Ringdal, K. (1999): Institutional and rational determinants of organizational practices: Human Resource Management in european firms. In: Administrative Science Quarterly, 44, 507-531.

Gouldner, A. W. (1960): The norm of reciprocity. In: American Sociological Review, 25, 161-178.

Graen, G. B. (1969): Instrumentality theory of work motivation: Some experimental results and suggested modifications. In: Journal of Applied Psychology Monographs, 56, 1-25.

Granovetter, M. S. (1978): Threshold models of collective behavior. In: American Journal of Sociology, $83,1420-1443$.

Granovetter, M. S. (1985): Economic action and social structure: The problem of embeddedness. In: American Journal of Sociology, 91, 481-510.

Heckhausen, H. (1989): Motivation und Handeln. 2. Aufl., Berlin/Heidelberg/New York et al.: Springer.

Hollander, E. P. (1958): Conformity, status and idiosyncrasy credit. In: Psychological Review, 65, 361365.

Homans, G. C. (1964): Bringing men back in. In: American Sociological Review, 29 (5), 808-818.

Homans, G. C. (1974): Social Behavior - Its elementary Forms. New York: Harcourt, Brace \& World.

Kabst, R. (2004). Internationalisierung mittelständischer Unternehmen. München/Mering: Hampp (in Druck).

Kelle, U./Lüdemann, C. (1995): „Grau, teurer Freund, ist alle Theorie ...“ Rational Choice und das Problem der Brückenannahmen. In: Kölner Zeitschrift für Soziologie und Sozialpsychologie, 47 (2), 249267.

Kirchgässner, G. (1991): Homo oeconomicus. Das ökonomische Modell individuellen Verhaltens und seine Anwendung in den Wirtschafts- und Sozialwissenschaften. Tübingen: Mohr (Siebeck).

Kluckhohn, C. (1962): Value and value orientations in the theory of action: An exploration in definition and classification. In: Parsons, T./Shils, E. (eds.), Toward a General Theory of Action, 388-433. New York: Harper \& Row.

Lazear, E. P. (1996): Personnel Economics. Cambridge/MA /London: MIT Press.

Levi-Strauss, C. (1971): The Elementary Strutures of Kinship. Boston: Beacon Press.

Lewin, K./Lippit, R./White, R. K. (1939): Patterns of aggressive behavior in experimentally created social climates. In: The Journal of Social Psychology, 10 (2), 271-299.

Lewin, K. (1951): Field Theory in Social Sciences. 2nd edition, New York: Harper.

Lindenberg, S. (1985): An assessment of the new political economy: Its potential for the social sciences and for sociology in particular. In: Sociological Theory, 3, 99-114.

Lindenberg, S. (1990): Homo socio-economicus: The emergence of a general model of man in the social sciences. In: Journal of Institutional and Theoretical Economics, 146, 727-748.

Lindenberg, S. (1992): The Method of decreasing abstraction. In: Coleman, J. S./Fararo, T. J. (eds.), Rational Choice Theory. Advocacy and Critique, 3-20. Newbury Park/London/New Delhi: Sage.

Lindenberg, S. (1996): Die Relevanz theoriereicher Brückenannahmen. In: Kölner Zeitschrift für Soziologie und Sozialpsychologie, 48 (1), 126-140.

March, J. G./Simon, H. A. (1993): Organizations. 2nd edition. Oxford: Blackwell.

Marsden, P. V. (1983): Restricted access in networks and models of power. In: American Journal of Sociology, 88, 686-717.

Matiaske, W. (1995): Zur Kontingenztheorie der Führung. Arbeitspapier Nr. 6, Wirtschaftswissenschaftliche Dokumentation. Technische Universität Berlin.

Matiaske, W. (1999): Soziales Kapital in Organisationen. Eine tauschtheoretische Studie. München/Mering: Hampp.

Matiaske, W. (2003): Tausch. In: Martin, A. (Hg.), Organizational Behaviour - Verhalten in Organisationen, 283-305. Stuttgart: Kohlhammer.

Mauss, M. (1989): The Gift: The Form and Reason for Exchange in Archaic Societies. London: Routledge. 
Meckling, W. H. (1976): Values and the choice of the individual in the social sciences. In: Schweizerische Zeitschrift für Volkswirtschaft und Statistik, 112, 545-560.

Mills, C. W. (1959): The Sociological Imagination. New York: Oxford University Press.

Neumann, J. v./Morgenstern, O. (1972): Theory of Games and Economic Behaviour. Princeton: Princeton University Press.

Olson, M. (1965): The Logic of Collective Action: Public Goods and the Theory of Groups. Cambridge/MA: Harvard University Press.

Ordelheide, D./Rudolph, B./Büsselmann, E. (Hg.) (1990): Betriebswirtschaftslehre und ökonomische Theorie. Stuttgart: Poeschel.

Pareto, V. (1935): The Mind and Society. S.1.: Cape.

Parsons, T. (1962): Some fundamental categories of the theory of action: A general statement. In: Parsons, T./Shils, E. A. (eds.), Toward a General Theory of Action, 3-27. New York: Harper \& Row.

Parsons, T. (1977): Social structure and the symbolic media of interchange, In: Social Systems and the Evolution of Action Theory, 204-228. New York: Free Press.

Pfeffer, J. (1994): Competitive Advantage through People: Unleashing the Power of the Work Force. Boston/MA: Havard Business School Press.

Popper, K. R. (1969): Die Logik der Sozialwissenschaften. In: Adorno, T. W. (Hg.), Der Positivismusstreit in der deutschen Soziologie, 103-123. Neuwied/Berlin: Luchterhand.

Popper, K. R. (1994): Models, instruments and truth: The status of the rationality principle in the social sciences. In: Notturno, M. A. (ed.), The Myth of the Framework: In Defence of Science and Rationality, 154-184. London: Routledge.

Putnam, R. D. (2000): Bowling Alone: The Collapse and Revival of American Community. New York: Simon \& Schuster.

Sadowski, D. (2002): Personalökonomie und Arbeitspolitik. Stuttgart: Schäffer-Poeschel.

Schoemaker, P. J. K. (1982): The expected utility model: Its variants, purposes, evidence, and limitations. In: Journal of Economic Literature, 20, 529-563.

Schumpeter, J. (1942): Capitalism, Socialism, and Democracy. 2nd edition, New York: Harper.

Simon, H. A. (1955): A behavioral model of rational choice. In: Quarterly Journal of Economics, 69, 99118.

Smith, A. (1911): Theory of Moral Sentiments. New edition, Bell.

Stigler, G./Becker, G. S. (1977): De gustibus non est disputandum. In: American Economic Review, 67, 76-90.

Swedberg, R. (2003): Principles of Economic Sociology. Princeton: Princeton University Press.

Vanberg, V. (1982): Markt und Organisation. Individualistische Sozialtheorie und das Problem korporativen Handelns. Tübingen: Mohr (Siebeck).

Veblen. T. (1924): Theory of the Leisure Class. S.l.: Allen \& Unwin.

Vroom, V. H. (1964): Work and Motivation. New York/London/Sydney: Wiley.

Wasserman, S./Faust, K. (1997): Social network analysis. Methods and applications. 2nd edition, Cambridge: Cambridge University Press.

Weise, P. (1989): Homo oeconomicus und homo sociologicus. Die Schreckensmänner der Sozialwissenschaften. In: Zeitschrift für Soziologie, 18 (2), 148-161.

Williamson, O. E. (1985): The Economic Institutions of Capitalism. New York: Free Press.

Wippler, R./Lindenberg, S. (1987): Collective phenomena and rational choice. In: Alexander, J. C./Giesen, B./Münch, R./Smelser, N. J. (eds.), The Micro-Macro Link, 135-152. Berkeley/Los Angeles/London: University of California Press.

Wrong, D. H. (1961): The oversocialized conception of man in modern soziology. In: American Sociological Review, 26, 183-193.

Yamaguchi, K. (1996): Power in networks of substitutable and complementary exchange relations: A rational-choice model and an analysis of power centralization. In: American Sociological Review, 61, 308-332.

Zalesny, M. D./Graen, G. B. (1995): Führungstheorien - Austauschtheorie. In: Kieser, A./Reber, G./Wunderer, R. (Hg.), Handwörterbuch der Führung, 862-877. 2. Aufl., Stuttgart: SchäfferPoeschel. 